\title{
POSTOPERATIVE PAIN FOLLOWING MULTI-VISIT ROOT CANAL TREATMENT OF TEETH WITH VITAL AND NON-VITAL PULPS
}

\author{
Farzana $\mathrm{F}^{1}$, Hossain $\mathrm{SMI}^{2}$, Islam $\mathrm{SMN}^{3}$, Rahman $\mathrm{MA}^{4}$
}

\begin{abstract}
Introduction: Post-obturation pain is one of the primary problems following root canal treatment. Although in most cases pain does not last long, but could be a source of embarrassment to the dentist and annoying for the patient.

Objectives: This prospective study was conducted to assess the incidence of postoperative pain after multivisit root canal treatment of teeth with vital and nonvital pulps.

Methods: Total, 52 patients with teeth requiring endodontic treatment were identified and included in this study. The patients were randomly assigned and treated in a military hospital and in government dental college hospital into two groups. The teeth of patients in group 1 were with vital inflamed pulp; group 2 were with non-vital pulp with or without periapical radiolucency $(0-5 \mathrm{~mm})$. Patients were treated in multiple visit procedure. They were asked whether they experienced any postoperative pain to rate the level of discomfort as no, mild, moderate, or severe pain. Data were analyzed statistically using the chi-square test.
\end{abstract}

Results: No significant difference in postoperative pain was found between vital and non-vital pulps $(p=0.2)$. Mild and moderate pain occurred in $4.34 \%$ and $4.34 \%$ respectively in teeth with vital pulp and $17.3 \%$ and $3.44 \%$ in teeth with non-vital pulp respectively. There was no significant difference in postoperative pain between the two groups $(p>0.05)$.

Conclusions: The incidence of postoperative pain did not differ between vital and non-vital teeth.

Key words: Postoperative dental pain, root canal treatment, vital and non-vital pulp

\section{Introduction}

The goal of root canal therapy is to shape, clean, disinfect and obturate canals without additional injury to the periradicular tissues ${ }^{1}$. The success of root canal treatment depends on a series of variables related to the preoperative condition of the tooth, as well as the endodontic procedures $^{2}$. Endodontic treatment can be followed by short and long term complications ${ }^{3}$. Some of the problems of root canal treatment are postobturation pain, interappointment pain and swelling. Although these in most cases do not last long, but could be a source of embarrassment to the dentist and annoying for the patient, more so if the tooth was symptomless before the commencement of treatment ${ }^{4}$. Postobturation pain is the pain of any degree after endodontic treatment ${ }^{5}$. Pain and swelling is often indicator of an offending tooth. Endodontic treatment aims to reverse the disease process and thereby eliminate the associated signs and symptoms ${ }^{6}$. Literature review revealed varied opinions on the incidence and severity of postobturation pain. The reported prevalence of postobturation pain or flare-up ranges from $0-65 \%{ }^{7}$. Certain factors may influence the progression of postoperative pain, such as a history of preoperative pain and the need for retreatment ${ }^{7-8}$. Although microorganisms are usually regarded as the most common cause of postoperative pain, other causes include mechanical or chemical injury to pulpal or periapical tissues 9 . There is a clear indication of interactions between periapical tissues and microorganisms, because flare-ups are more likely to occur in necrotic cases than in vital cases ${ }^{5,10}$. This could indicate a clear relationship between pulp status and postoperative pain, even after successful endodontic therapy ${ }^{11}$. However, limited data regarding the relationship between postoperative pain and the vitality of the pulp before endodontic treatment are available in the literature.

Some authors reported slightly more postobturation pain following single visit than with multiple visit procedures ${ }^{12,13}$. Others found no significant differences in the postobturation pain experienced by patients following single or multiple visit treatment procedures ${ }^{14}$. Fox et al in their study showed that female patients had more postoperative pain than did males. Factors of age, bacteriological status, tooth position and type of filling material showed no clear effect upon post-operative results ${ }^{15}$. 
Until recently the most accepted technique of doing endodontic treatment stresses multiple-visit procedures ${ }^{4}$. The completion of endodontic therapy in a single appointment has been currently used ${ }^{16,17}$. Although the argument for single-visit treatment depends on the convenience, patient acceptance, and reduced postoperative pain ${ }^{18}$, multiple-visit root canal therapy has long been taught as a safer procedure than single-visit root canal therapy ${ }^{4,16}$. Furthermore, when flare-ups occur during multi-visit procedures, they can be addressed before obturation, but this is not an option in a singlevisit regimen ${ }^{13}$. In addition, bacterial eradication cannot be maximized predictably without using a calcium hydroxide dressing between appointments, therefore, the potential for healing may be compromised ${ }^{19}$.

This clinical study was aimed to determine the incidence of pain following multiple-visit root canal treatment in vital versus non-vital teeth and evaluated the association between the incidence of pain and pulp status.

\section{Materials and Methods}

Consenting patients referred to the Department of Conservative Dentistry and Endodontics, Dhaka Dental College \& Hospital and Combined Military Hospital, Dhaka for root canal therapy within a period of twelve months were randomly assigned for multiple visit treatment. Patients with vital and non-vital pulp with or without periapical radiolucency $(0-5 \mathrm{~mm})$ were included in the study. Patients that defaulted after first appointment (incomplete treatment) were excluded from the study. For each tooth treated, the clinical factors and conditions existing before, during and after the completion of treatment were recorded. This data included pulp vitality status, the presence or absence of preoperative pain, postobturation flare-ups and degree of post-obturation pain. For patients requiring root canal treatment on more than one tooth was separated by a period of four weeks to allow for proper evaluation. The pulp vitality was determined by cold thermal test in combination with the presence of pulpal haemorrhage. The non-vital status of pulps was determined each by cold thermal test with negative response, palpation, percussion and radiographic examination.

After administering local anaesthesia using 2\% lignocaine 1:80,000 epinephrine (where needed), tooth was isolated and an access cavity was made and working length was determined radiographically. After access was obtained, the teeth were grouped into Group 1 (vital pulp) and Group 2 (non-vital pulp).Instrumentation was performed using crown-down technique. During instrumentation, all canals were flushed with $1 \%$ sodium hypochlorite solution. Calcium hydroxide was used as intracanal medicaments. After one week, the root canals were obturated with multiple gutta-percha points and a zinc-oxide based sealer, using the lateral condensation technique.
The patients were recalled at three specific postobturation periods, 1 st, 7 th and 30 th day. At each postobturation recall visit, the patients were interviewed to determine whether or not there were symptoms at the present visit and whether or not there were symptoms during the interval between visit and the previous one. The presence or absence of pain, or the appropriate degree of pain was recorded for each recall visit and the interval between visits. Pain was recorded as none, slight, moderate, or severe ${ }^{16}$ :

- No pain: The treated tooth felt normal. Patients did not have any pain.

Mild pain: Recognizable pain, but not discomforting, III which required no analgesics.

- Moderate pain: Discomforting pain, but bearable (analgesics, if used, were effective in relieving the pain).

- Severe pain: Difficult to bear (analgesics had little or no effect in relieving the pain).

The compiled data were analyzed using chi-square where applicable. Differences were taken as significant if $\mathrm{p}<0.05$.

\section{Results}

The study comprises 52 cases of pulp pathosis with vital and non-vital pulp requiring root canal therapy. Of the 52 cases, 29 were males and 23 were females. Out of that 9 male and 8 female patients complained of pain. The male patients experienced more postobturation pain than female patients, of course the difference was not statistically significant $(\mathrm{p}=0.52)$. A comparison of pain experience in relation to pre-treatment pulpal vitality revealed that those with vital pulp had a lower frequency of postobturation pain $(26.0 \%$ and $8.6 \%$ on 1 st and 7 th postoperative day, respectively) than those with non-vital pulp (37.8\% and $20.6 \%$ on 1 st and 7 th postoperative day, respectively).

Table-I: Tooth distribution between treatment group.

\begin{tabular}{|l|c|c|}
\hline \multicolumn{1}{|c|}{ Tooth types } & $\begin{array}{c}\text { Vital Pulp (n=23) } \\
\text { Number (\%) }\end{array}$ & $\begin{array}{c}\text { Non-Vital } \\
\text { Pulp (n=29) } \\
\text { Number (\%) }\end{array}$ \\
\hline Maxillary incisors & $5(21.73)$ & $6(20.68)$ \\
\hline Maxillary canines & $0(0)$ & $1(03.44)$ \\
\hline Maxillary premolars & $1(04.34)$ & $3(10.34)$ \\
\hline Maxillary molars & $9(39.13)$ & $2(06.89)$ \\
\hline Mandibular incisors & $1(04.34)$ & $5(17.24)$ \\
\hline Mandibular canines & $0(0)$ & $2(06.89)$ \\
\hline Mandibular premolars & $0(0)$ & $3(10.34)$ \\
\hline Mandibular molars & $7(30.43)$ & $7(24.13)$ \\
\hline
\end{tabular}

The difference between postobturation pain in vital and non-vital group was not significant $(p>0.05)$. The percentage of patient with mild/ moderate pain on the 7 th postobturation day was higher for non-vital group. None reported with severe pain with this shorter period. No postobturation pain persisted to the 30 th day. 
Table-II: Incidence and distribution of pain level on 1st post obturation day $(\mathrm{n}=52)$.

\begin{tabular}{|l|l|l|l|c|}
\hline Group & $\begin{array}{c}\text { No pain } \\
\text { No (\%) }\end{array}$ & $\begin{array}{c}\text { Mild pain } \\
\text { No (\%) }\end{array}$ & $\begin{array}{c}\text { Moderate } \\
\text { pain } \\
\text { No (\%) }\end{array}$ & $\begin{array}{c}\text { Severe } \\
\text { pain } \\
\text { No (\%) }\end{array}$ \\
\hline Vital $(\mathrm{n}=23)$ & $17(73.9)$ & $5(21.79)$ & $1(04.34)$ & $0(0)$ \\
\hline Non-Vital $(\mathrm{n}=29)$ & $18(62.06)$ & $6(20.68)$ & $5(17.40)$ & $0(0)$ \\
\hline $\begin{array}{l}\text { Incidence of pain } x^{2}=0.9, \mathrm{df}=1, \mathrm{p}=0.34 . \\
\text { Percentage incidence of pain, vital=26.0 } \\
\text { Percentage incidence of pain, non-vital=37.8. }\end{array}$ \\
\hline
\end{tabular}

Table-III: Incidence and distribution of pain level on 7 th postobturation day $(\mathrm{n}=52)$.

\begin{tabular}{|c|c|c|c|c|}
\hline Group & $\begin{array}{l}\text { No pain } \\
\text { No }(\%)\end{array}$ & $\begin{array}{l}\text { Mild pain } \\
\text { No }(\%)\end{array}$ & $\begin{array}{c}\text { Moderate } \\
\text { pain } \\
\text { No }(\%)\end{array}$ & $\begin{array}{c}\text { Severe } \\
\text { pain } \\
\text { No }(\%)\end{array}$ \\
\hline Vital $(n=23)$ & $21(91.30)$ & $1(04.34)$ & $1(04.34)$ & $0(0)$ \\
\hline Non-Vital $(n=29)$ & $23(79.31)$ & $5(17.27)$ & $1(03.44)$ & $0(0)$ \\
\hline \multicolumn{5}{|c|}{$\begin{array}{l}\text { Incidence of pain } x^{2}=1.4, \mathrm{df}=1, \mathrm{p}=0.23 \text {. } \\
\text { Percentage incidence of pain, vital= } 8.6 \\
\text { Percentage incidence of pain, non-vital=2 }\end{array}$} \\
\hline
\end{tabular}

On 1 st postobturation day $73.9 \%$ patient with vital pulp (group 1) and $62.06 \%$ patient with non-vital pulp (group 2) experienced no pain. The relation between preoperative and postobturation pain and the comparison of postobturation pain in non-vital with or without radioluscency was not established in the present study.

\section{Discussion}

The success and failure of endodontic treatment is determined by long-term results and not the presence or absence of short-term post-operative pain. A root canal treatment with post-operative pain can result in longterm success, whereas treatment without postoperative pain may result in failure ${ }^{20}$. However, postoperative pain is an important issue for both dentists and patients considering expectation of relief of pain through root canal treatment especially in symptomatic irreversible pulpitis.

This study clearly showed that the degree and frequency of postobturation pain related to multivisit root canal treatment did not differ in vital and non-vital group $(p=0.2)$. This finding is in agreement with findings of several studies ${ }^{15,21}$, who reported that whether a tooth pulp was vital or not had little effect on postobturation pain.

Despite the high percentages of postobturation pain reported on the first postobturation day in both groups, after seven days of obturation $91.30 \%$ in vital group and $79.31 \%$ in non-vital group were free of symptoms. Also, since no postobturation pain persisted to the 30th day in both groups, these present a strong indication that practitioners should not overreact to early postobturation symptoms by immediately initiating endodontic retreatment procedures or extraction of the involved tooth $^{4}$.

In this study, male patients experienced more pain than the female, though the number was not statistically significant. This finding is in agreement with Bayram Ince et $\mathrm{al}^{22}$. But in disagreement with Genet et al, Fox et al and Mulhern et al, who described that women suffer more $^{11,15,23}$.

The present study showed, pain was highest in 31-40 years age group, the next higher group was 21-30 years age group. These findings are nearly with the findings consistent of $\mathrm{O}^{\prime}$ Kefee, Torabinejad and Cheng et $\mathrm{al}^{4,24,25}$. They found more pain in older patients (25 years and above). The higher incidence of postobturation pain in the elderly group might be experienced by previous pain experience and a reduced ability to tolerate pain and discomfort.

\section{Conclusions}

Multiple visit root canal therapy may be considered as the primary, safe and effective method in managing pulp pathosis with vital inflamed as well as non-vital pulp with or without radiolucency. Preoperative status of the pulp is of prime importance, but the other factors of importance not included in this study which may influence the treatment outcome deserve further investigations and may strongly influence the conclusion made.

\section{Refernces}

1. Senia ES. Canal diameter: the forgotten dimension. Endod Prac 2000; 3: 34-8.

2. Figini L, Lodi G, Gorni F, Gagliani M. Single versus multiple visits for endodontic treatment of permanent teeth: A Cochrane Systemic review. Journal of Endodontics 2009; 34 (9): 1041-47.

3. Glenon JP, Ng YL, Setchell DJ, Gulabirvala K. Prevalence of and factors affecting postoperation pain in patients undergoing two-visit root canal treatment. International Endodontic Journal 2004; 37: 29-37.

4. Oginni AO, Udoye CI. Endodontic Flare-ups: Comparison of incidence between single and multiple visit procedures in patients attending a Nigerian teaching Hospital. BMC Oral Health 2004; 4(1): 4. 5. Walton R, Fouad A. Endodontic interappointment flare-ups: A prospective study of incidence and related factors. Journal of Endodontics 1992; 18 (4): 172-7.

6. Sathhorn C, Parashos P, Messer H. The prevalence of postoperative pain and flare-up in single and multiple-visit endodontic treatment; a systemic review. International Endodontic Journal 2007; 41: 91-99.

7. Fava LR. A comparison of one versus two-appointment endodontic therapy in teeth with non-vital pulps. International Endodontic Journal 1991; 24: 258-62.

8. Imura N, Zuolo ML. Factors associated with endodontic flare-ups: a prospective study. International Endodontic Journal 1995; 28: 261-265.

9. Siquera JF Jr, Rocas IN, Favieri A, et al. Incidence of post-operative pain after intracanal procedures based on an antimicrobial strategy. Journal of Endodontics 2002; 28: 457-460.

10. Seltzer S, Naidorf IJ. Flare-ups in endodontics: Etiological factors. International Journal of Endodontics 1985; 11: 472-478.

11. Genet JM, Wesselink PR, Thoden Van Velzen SK. Preoperative and operative factors associated with pain after the first endodontic 
visit. . International Journal of Endodontics 1987; 20: 53-64.

12. Clem W. Post treatment endodontic pain. Journal of American Dental Association 1972; 81: 1166-70.

13. Soltanoff WA. A comparative study of single visit and multiple visit endodontic Procedures. Journal of Endodontics 1978; 4: 278-81.

14. O'Keefe EM. Pain in endodontic therapy: preliminary study. Journal of Endodontics 1976; 2: 15-19.

15. Fox JJ, Atkinson JS, Dinin AP, et al. Incidence of pain following one visit endodontic treatment. Oral Surgery 1970; 30: 123-30.

16. Albashaireh ZS, Alnegrish AS. Postobturation pain after single and multiple visit endodontic therapy. Journal of Dentistry 1998; 26: 227-232. 17. Qualtrough AJ, Whitworth JM, Dummer PM. Preclinical endodontology: an international comparison. International Journal of Endodontics 1999; 32: 406-414

18. Inamoto K, Kojima K, Nagamatsu K, Hamaguchi A, Nakata K, Nakamura H. A survey of the incidence of single-visit endodontics. Journal of Endodontics 2002; 28: 371-374.

19. Spangberg LS. Evidence-Based endodontics: the one-visit treatment idea. Oral Surg Oral Med Oral Pathol Oral Radiol Endod 2001;91:617-618
20. Mattscheck DJ, Law AS, Noblett WC. Retreatment versus initial root canal treatment: factors affecting posttreatment pain. Oral Surg Oral Pathol Oral Radiol Endod 2001; 92: 321-4.

21. Roane JB, Dryden JA, GrimesW. Incidence of postoperative and pain in endodontic therapy. Oral Surgery 1983; 55: 68-72.

22. Bayram I, Ertugrul E, Mehmet D, al, Incidence of postoperative pain after single and multi-visit endodontic treatment in teeth with vital and non-vital pulp. European Journal of Dentistry 2009; 3 (4): 273-279. 23. Mulhern JM, Peterson SS, Newton CW, Ringel AM. Incidence of postoperative pain after one appointment endodontic treatment of asymptomatic pulpal necrosis in single rooted teeth. Journal of Endodontics 1982; (8): 370-5.

24. Torabinejad M, Kettering JD, McGraw JC, Cummings RR, Dwyer TG. Factors associated with endodontics interappointment emergencies of teeth with necrotic pulps. Journal of Endodontics 1998, 14: 261-6.

25. Cheng Y, Cheung GSP, Bian Z, Peng B. Incidence and factors associated with endodontic interappointment emergency in a dental teaching hospital in china. Journal of Dentistry 2006; 34: 516-21. 